\title{
Analysis of Student Problem Solving Skill and Activity Concentration on a Senior High School
}

\author{
Ratni Purwasih ${ }^{1}$, Heris Hendriana ${ }^{2}$, Erwin Trawan ${ }^{3}$, Yudi Prasetio ${ }^{4}$, Trisatria ${ }^{5}$ \\ 1,2,3,4,Program Studi Pendidikan Matematika IKIP Siliwangi \\ ${ }^{1}$ Correspondence Address; ratnipurwasih61@gmail.com
}

\begin{abstract}
The aim of the research to know the level of student problem solving skill of Senior high school students on their mathematical problem and activity concentration. The object of the research was conducted at one of Senior high school of Cimahi. the Subject of the research is all twelve grades of Senior high School Students of Science Program in Cimahi. The research used descriptive qualitative research to describe the student analysis error on doing the question of problem solving ability. The data of the research was found using diagnostic of series and rows and also student questionnaire. Data collecting technique used Miles and Huberman concept that are reduction data, reporting data and draw the conclusion. The result of the research are: (1) the level of the ability to solve the problem is still low (2) the common student error did not understand the questions and have no ability to communicate in mathematical form. (3) the student's activity is rated strong. Some solutions can be given to increase student problem solving ability through practice or question drill structured and gived the variety questions as material practice.
\end{abstract}

Key Words: Problem Solving Skill; Student Activity.

\section{INTRODUCTION}

The development of technology and communication are part of the development of knowledge and technology currently. This has an impact on the ability to be owned by a person in the face of the necessary critical thinking skills, systematic , logic, creative, and the ability to work effectively together. The Attitude and the concept can be developed through a process of activity that gives the opportunity for rational thinking. One of process is mathematics learning because mathematics has a strong structure and interrelationships between the concepts and others. The mathematical skills listed on NCTM (2000) that are problem solving, reasoning and verification, interconnection, communication, and representation. Syaban (2008) state that the abilities is called mathematical power or doing math. One of doing math which is closely related toward characteristics of mathematics is the problem-solving ability.

The aims of mathematical learning for the students are able to solve and solve problems, design mathematical models, implement mathematics in life, and have good affective (Amir, 2015). The affective attitude includes a curiosity, attention, active, and interest in learning math, as well as a tenacious attitude and confidence in problem solving. The mathematical problem solving skill and students activity that something important in education of mathematic and more practice from basic grade education up to university.

Problem solving skill is important to be owned for every students because its skill is focus of mathematical learning (Amir, 2015; Sundayana, 2018). Sariningsih \& Purwasih 
(2017) state that problem solving skill is the central of the process mathematical learning and basic skill in studying mathematics. According to Polya (Widyastuti, 2015), there are four steps can be used on problem solving, those are understanding the problem, devising a plan, carrying out the plan, looking back. In addition to the cognitive aspects, we need to also look at the affective aspects of the learning process.

One of the affective aspects is student learning activeness. Leaning activeness can be defined an activity that is done by students during the learning process that involves physical aspects and spiritual aspects that can be developed by teachers to achieve learning objectives (Vitasari, 2013). Hendriana (2014) argues that the students learning activities can be developed and also optimized through various interactions and learning experiences, so it can be concluded that student learning activeness is one of the basic elements that are important for the success of the learning process. Student activity in learning activities aim to construct their own knowledge. They actively build an understanding of the problem or everything they face in the learning process. Student activity are expected to make their own observations, their own experiences, their own inquiry, by working alone with the facilities created in optimal teaching and learning activities that can create a conducive classroom atmosphere.

Harahap in Vitasari (2013) stated that the indicators student learning active can be classified as follows: a) students response on teacher motivation, b) understand the problems in the student worksheet (LKS), c) solve the problem or determine the answer and try to answer, d) reproduce opinion, e) discussing between teachers and students , f) present the result of group work, g) summarizes the material that has been discussed. In addition to improving student attachment is also explained how to increase student attachment or student activeness in learning.

Base on argument above, the authors can be concluded that the problem-solving ability and learning activities of students are two very important things. Therefore, the authors are interested to analyze these two things in the students themselves.

\section{THE RESEARCH METHODS}

The method of the research that was used in this research is descriptive qualitative and the aim of the research to describe the ability of problem solving mathematical and student activeness, as proposed by Lexy (2007) that qualitative descriptive is research done to understand phenomenon experienced by research subject related to behavior, perceptions, actions, etc., holistically and by way of description of words and language, to a specific scientific context and by utilizing various scientific methods.

The research instruments were used tests and non-tes. The test instrument is about mathematical problem solving ability. The Instrument test given to the students are 4 items. Non test instrument is used the questionnaire of student activeness of Likert scale used four choices of answers, namely: Strongly Agree (SS), Agree (S), Disagree (TS), and Strongly Disagree (STS) with score 4, 3, 2, and 1 for positive statements, for negative statements the score is the opposite of 1, 2, 3 and 4. These four options mean avoiding student opinions on a proposed statement so that on the student's scale of opinion no use of the Neutral $(\mathrm{N})$. 
Questionnaire student activeness is used in statement form that is 20 statements to know how far the studnts activity on subject mathematics material. To know the matematichal problem solving skill the author do the scoring student's answer for each item that is adjusted with result of scoring each item, then the author analyze the result student answer. Meanwhile, to know the the student active, the author sees the level of the scores of questionnaires that have been answered by the students. Data analysis techniques that is used of the concept of Miles and Huberman, namely data reduction, reported data, and conclusion (Sugiyono, 2011). Classification of student activeness was analyzed to interpretation of presentage creteria classification of attitude scale showed by Riduwan (2007):

Table 1. Criteria Classification Percentage on Scale Attitude Learning Activity

\begin{tabular}{cl}
\hline The Final criteria grade $(\mathbf{N A})(\boldsymbol{\%})$ & Classification \\
\hline $\mathbf{0} \leq \boldsymbol{N A} \leq \mathbf{2 0}$ & Very poor \\
$\mathbf{2 0}<\boldsymbol{N A} \leq \mathbf{4 0}$ & Weak \\
$\mathbf{4 0}<\boldsymbol{N A} \leq \mathbf{6 0}$ & Enough \\
$\mathbf{6 0}<\boldsymbol{N A} \leq \mathbf{8 0}$ & Strong \\
$\mathbf{8 0}<\boldsymbol{N A} \leq \mathbf{1 0 0}$ & Very Strong \\
\hline
\end{tabular}

\section{THE RESULTS OF THE RESEARCH AND THE DISCUSSION}

In a table 2., the results below shows about the students problem-solving abilities mathematically on the subject material of statistics.

Tabel 2. The Average Student grade on Mathematical Problem Solving Skill

\begin{tabular}{|c|c|c|c|c|c|}
\hline \multirow[t]{2}{*}{ No } & \multirow{2}{*}{$\begin{array}{r}\text { The } \\
\text { Indicator }\end{array}$} & \multirow[t]{2}{*}{ SMI } & \multicolumn{3}{|l|}{ Total } \\
\hline & & & Score & $\bar{X}$ & $\%$ \\
\hline 1 & $\begin{array}{l}\text { report the problem in a } \\
\text { clearer form }\end{array}$ & 5 & 146 & 4,17 & 83,4 \\
\hline 2 & $\begin{array}{l}\text { Stating the problem in an } \\
\text { operational (unbreakable) } \\
\text { form }\end{array}$ & 5 & 150 & 4,3 & 86,0 \\
\hline 3 & $\begin{array}{l}\text { arrange } \\
\text { hypotheses and working } \\
\text { procedures that are well- } \\
\text { thought out for use in its } \\
\text { problem. }\end{array}$ & 5 & 120 & 3,4 & 68,0 \\
\hline 4 & $\begin{array}{l}\text { Test the hypothesis and do } \\
\text { the research to get the results } \\
\text { (data collection, data } \\
\text { processing, and others) }\end{array}$ & 5 & 150 & 4,3 & 86,0 \\
\hline & The Total Research & 20 & 566 & 4,04 & 80,86 \\
\hline
\end{tabular}

The result of students' mathematical problem solving test is listed in Table 2. Show the overall average score results in which indicator 1 with an average of 4.17 . Indicators 2 and 4 
with an average of 4.3 are the highest percentages. Indicator 3 with an average of 3.4. While on the indicator 4 with an average of 4.3. Figure 1. below is the result of the student's answer in solving the problem of mathematical problem solving skills:

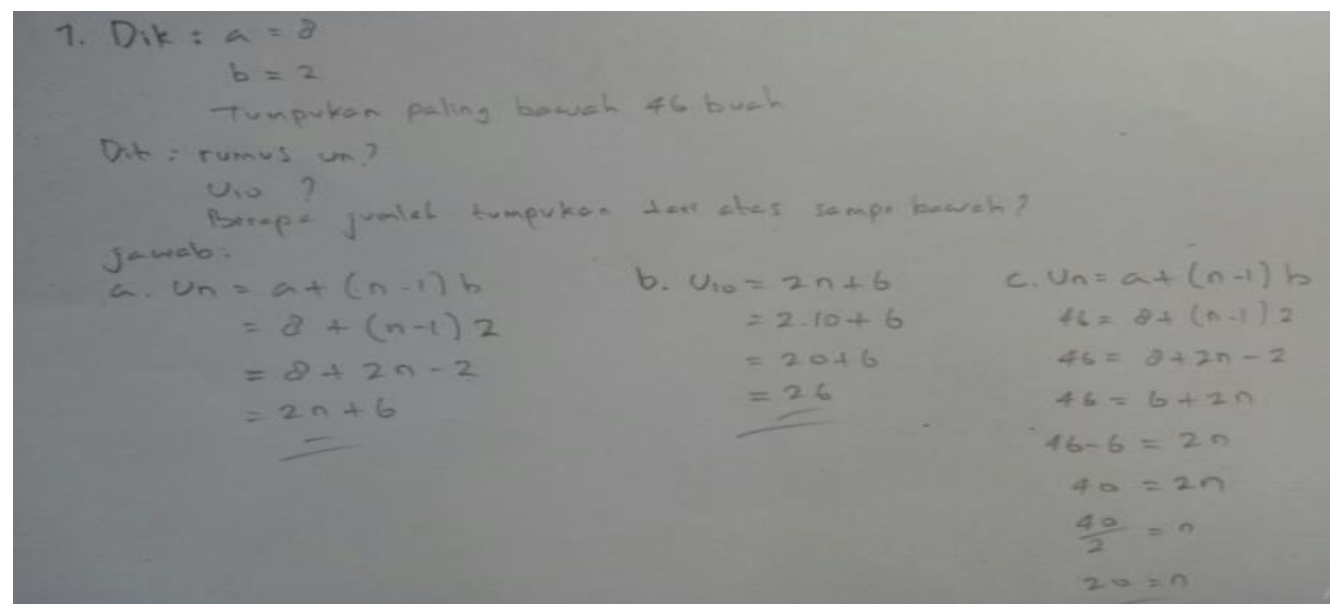

(a)

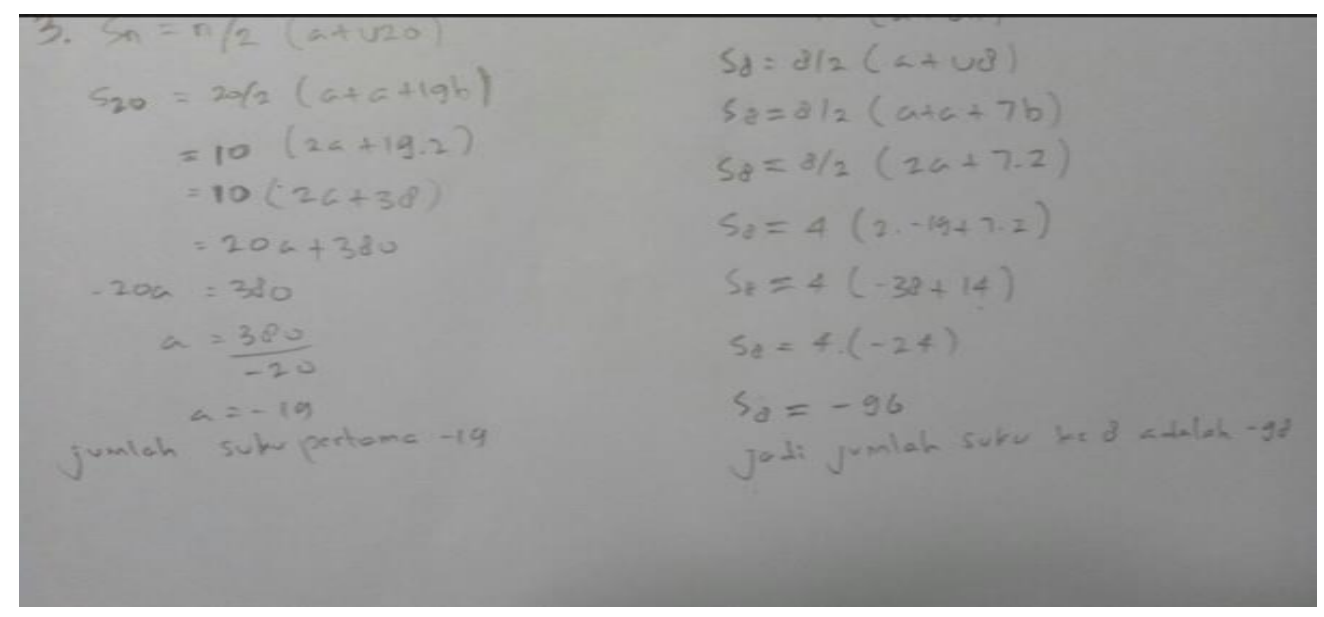

(b)

Figure 1. The Results of Student Answers

Figure 1(a) indicates that the indicator "presents the problem" in the clearer form, it showed student could answer clearly and in accordance with the stages. Thus, the answer gave an illustration that indicator 1 of students' mathematical problem solving ability could be achieved with the highest percentage value. The process of problem solving skills was a general goal of teaching mathematics so that students who had been able to give the solution to the question could be indicated that the problem solving ability was in students. It was in line with the pattern that the problem-solving process involves understanding the problem, making a plan for solving / planning the solving, doing the calculation, re-examining the results obtained. At figure 1(b) students were not careful in solving the problems that had been presented. Thus, it could be said that students in the test of mathematical problem solving ability provided an illustration that students' mathematical problem solving skills had 
not been the same. Because many of them still could not solve the problem. That means students still had difficulties in mastering the concept of material sequence and arithmetic series. Indicator 3 is the lowest percentage of results indicators.

Generally it could be seen of the results of each question item gave an llustrasion that students were mostly able to do the calculation but the process sometimes could be missed. The probability based on the analysis was that students had not understood what was implied in the item, the students were still unable to change the model of problem solving skills to mathematical form, they had not been able to communicate the problem to the expected form , and the students were accustomed to do the routine questions. This is in line with the opinions of Aripin \& Purwasih (2017) stated that collecting information students working and practicing questionsons regularly will improve mathematical thinking with the understanding and problem solving ability will be installed in their cognitive domain. Rahmawati (2017) argues that the effect of miss understanding the material, the subject made some mistakes in doing the questions and did not understand the given problem, as suggested by (Budiyono, 2008) students make mistakes in the first step if students can understand the meaning of the questions. If students make mistakes in the first step, eventually students will also make mistakes in the next step. But there were also errors on careful finishing questions.

The Author did analysis of student activeness by giving the questionnaire. It involves 8 indicators used to identify statements and obtain the data to see the students' ability to solve mathematical problems by looking at student responses on the questionnaire. Student answers were scored and calculated using the Likert scale in each statement. Here is the result of the data analysis of the liveliness presented in Table 3.

Table 3. The Result of Descriptive Data Analysis of Student Activity

\begin{tabular}{|c|c|c|c|c|c|}
\hline \multirow[t]{2}{*}{ Indicators } & \multirow{2}{*}{$\begin{array}{l}\text { The number } \\
\text { of } \\
\text { statements }\end{array}$} & \multicolumn{3}{|l|}{ Total } & \multirow[t]{2}{*}{ categories } \\
\hline & & Score & $\bar{I}$ & $\%$ & \\
\hline Reading The Material & 4 & 430 & 3,071 & 76,5 & Strong \\
\hline $\begin{array}{l}\text { Asking, put the forward } \\
\text { ideas / thoughts }\end{array}$ & 3 & 334 & 3,18 & 79 & Strong \\
\hline Discussion & 2 & 226 & 3,23 & 80,5 & Strong \\
\hline $\begin{array}{l}\text { Listening the Material } \\
\text { Lesson }\end{array}$ & 2 & 240 & 3,43 & 85,5 & Strong \\
\hline $\begin{array}{l}\text { Making Summary of the } \\
\text { Lesson }\end{array}$ & 2 & 182 & 2,6 & 64,5 & Enough \\
\hline $\begin{array}{l}\text { Doing the exercise practice, } \\
\text { actively collect the idea and } \\
\text { record the research results }\end{array}$ & 2 & 213 & 3,04 & 75,5 & Enough \\
\hline $\begin{array}{l}\text { Solving the problem, and } \\
\text { analyze the problem }\end{array}$ & 2 & 219 & 3,13 & 77,5 & Strong \\
\hline
\end{tabular}




\begin{tabular}{|c|c|c|c|c|c|}
\hline \multirow[t]{2}{*}{ Indicators } & \multirow{2}{*}{$\begin{array}{l}\text { The number } \\
\text { of } \\
\text { statements }\end{array}$} & \multicolumn{3}{|l|}{ Total } & \multirow[t]{2}{*}{ categories } \\
\hline & & Score & $\mathbf{X}$ & $\%$ & \\
\hline Spirit and brave & 3 & 305 & 2,9 & 72,3 & Enough \\
\hline Total & 20 & 2149 & 24.58 & 76,41 & Strong \\
\hline
\end{tabular}

In Table 3., it can be seen that the result of student questionnaire shows that the average total score is $76,41 \%$ included in the strong classification. The indicator at number 4 is listening to the subject material is the most of the present score is $85.5 \%$. Students' activities during teaching and learning prefer to listen their teachers or friends. In addition, the liveliness of listening to the subject material also occurs during the discussion. Submission of material during the discussion involves all the students in the class. It supports the listening indicator of the material has the largest percentage among others. The ability of this one is the lowest percentage of $64.5 \%$ (make a summary of the material). Most students are less interesting to do the activity to summarize the subject Material of being studied. Students tend to copy or capture the summary results from other friends. This makes the prolem in learning because other writing make the student less understood by themselve.

According to Putra (2017), the factors that were influence the success of students 'mathematical problem solving skills in class are the students' freedom to build knowledge in the learning process to make the classroom students better prepared for active learning. he Result from Putra's (2017), showed that students are more independent and have better problem-solving skills in the classroom when using contextual learning. Purwasih (2015) said that students who have good understanding skills will have an impact on their problemsolving skills, because the first stage in solving the mathematical problem is the students must understand what the meaning of the questions. Through understanding of students are able to write down the components and elements are known in the next questions to perform the calculations and solving questions with material implication.

\section{CONCLUSION AND SUGGESTION}

Based on the results of research and discussion can be concluded that in general the ability of problem solving mathematical students is good, this means that students have attitudes adjust to learning mathematics. Especially the stage of making a plan for devising a plan, and carrying out the plan. Activity of students in general classified as a strong category, especially on indicators listening to material explanations. Based on the above conclusions, as for suggestions that can be submitted that is after knowing the description of problem solving analysis in solving the problem of series and sequence will be expected students can give more deep understanding of the material following up this research by examining the analysis error and giving scaffolding to solve it. For the further research is suggested to see the improvement of each indicator of mathematical problem solving ability and other capabilities that can be analyzed. 


\section{REFERENCES}

Amir, M. F. (2015). Pengaruh Pembelajaran Kontekstual Terhadap Kemampuan Pemecahan Masalah Matematika Siswa Sekolah Dasar. dalam Prosiding Seminar Nasional Pendidikan (hlm. 34-42).

Aripin, U., \& Purwasih, R. (2017). Penerapan Pembelajaran berbasis Alternative Solutions Worksheet untuk Meningkatkan Kemampuan Berpikir Kreatif. AKSIOMA: Jurnal Program Studi Pendidikan Matematika, 6(2), 225-233.

Budiyono, B. (2008). Kesalahan Mengerjakan Soal Cerita dalam Pembelajaran Matematika. Paedagogia, 11(1), 1-8

Hendriana, H. (2014). Meningkatkan Kemampuan Matematik Siswa melalui Pembelajaran berbasis Masalah dan Strategi Think Talk and Write. Edusentris, 1(1), 27-38.

Lexy, J. M. (2007). Metodologi Penelitian Kualitatif Edisi Revisi. Bandung: PT Remaja Rosdakarya.

NCTM. (2000). Principles and standards for school mathematics (Vol. 1-1). National Council of Teachers of.

Purwasih, R. (2015). Peningkatan Kemampuan Pemahaman Matematis dan Self Confidence Siswa MTS di Kota Cimahi Melalui Model Pembelajaran Inkuiri Terbimbing. Didaktik, 9(1), 16-25.

Putra, F. G. (2017). Eksperimentasi Pendekatan Kontekstual Berbantuan Hands On Activity (HoA) Terhadap Kemampuan Pemecahan Masalah Matematik. Al-Jabar: Jurnal Pendidikan Matematika, 8(1), 73-80.

Rahmawati, A. (2017). Analisis Kesalahan Mahasiswa Pendidikan Matematika Dalam Menyelesaikan Soal Pertidaksamaan Pada Mata Kuliah Kalkulus I. Al-Jabar: Jurnal Pendidikan Matematika, 8(1), 81-90.

Riduwan. (2007). Dasar-dasar Statistika. Bandung: Alabeta.

Sariningsih, R., \& Purwasih, R. (2017). Pembelajaran Problem Based Learning Untuk Meningkatkan Kemampuan Pemecahan Masalah Matematis Dan Self Efficacy Mahasiswa Calon Guru. JNPM (Jurnal Nasional Pendidikan Matematika), 1(1), 163177.

Sugiyono. (2011). Metode Penelitian Pendidikan (Pendekatan Kuantitatif, Kualitatif, dan $R$ \& D). Bandung: Alfabeta.

Sundayana, R. (2018). Kaitan antara gaya belajar, kemandirian belajar, dan kemampuan pemecahan masalah siswa SMP dalam pelajaran matematika. Mosharafa: Jurnal Pendidikan Matematika, 5(2), 75-84.

Syaban, M. (2008). Menumbuhkembangkan Daya Matematis Siswa. Educare, 5(2). 
Vitasari, R. (2013). Peningkatan Keaktifan dan Hasil Belajar Matematika Melalui Model Problem Based Learning Siswa Kelas V SD Negeri 5 Kutosari. Kalam Cendekia PGSD Kebumen, 4(3).

Widyastuti, R. (2015). Proses Berpikir Siswa dalam Menyelesaikan Masalah Matematika berdasarkan Teori Polya ditinjau dari Adversity Quotient Tipe Climber. Al-Jabar: Jurnal Pendidikan Matematika, 6(2), 183-194. 